\title{
PREFERENSI LOKASI INDUSTRI BERBASIS POTENSI LOKAL DI KABUPATEN BANYUMAS
}

\author{
Industrial Location Preferences: The Case of Local Based Industries \\ (IBPL) in Banyumas Regency, Central Java Province.
}

\section{Muhammad Abdullah Tsani ${ }^{1}$ and Prihadi Nugroho ${ }^{2}$}

Diterima: 4 Oktober 2017

Accepted: 16 Agustus 2018

\begin{abstract}
Abstrak: Lokasi pengembangan industri di Indonesia seringkali lebih ditentukan oleh kebijakan alokasi ruang daripada preferensi pelaku industri. Hal ini menimbulkan kesenjangan antara kebijakan dan kebutuhan lokasi yang ditandai penolakan pelaku industri terhadap lokasi yang ditawarkan di dalam kebijakan. Industri merupakan aktivitas bisnis dan lokasinya dipilih di tempat yang paling menguntungkan serta dipengaruhi oleh faktor-faktor lokasi. Namun pemilihannya tidak hanya menekankan pada preferensi pelakunya saja, tetapi dipengaruhi juga oleh strategi dan kebijakan dalam lingkungan organisasi besar di pemerintah pusat dan daerah. Penelitian ini menggunakan pendekatan kuantitatif untuk mengkaji preferensi lokasi industri berbasis lokal (IBPL) di Kabupaten Banyumas, Jawa Tengah, Indonesia. Tujuannya untuk mengevaluasi kebijakan alokasi ruang industri setempat, sehingga kesenjangan yang dimaksud dapat dikurangi. Temuan studi menunjukkan bahwa preferensi lokasi IBPL berhubungan dengan karakteristik konten lokal dan skala industri. IBPL menengah dan besar diketahui mengelompok, preferensi lokasinya cenderung mendekati industri pemasok dan berada di jalur pergerakan utama. Persebaran lokasi IBPL kecil diketahui menunjukkan gejala lokasi spontan dan dipengaruhi oleh faktor aksesibilitas potensi lokal terhadap tenaga kerja. Terdapat sepuluh faktor lokasi yang mempengaruhi pemilihan lokasi IBPL dan cenderung menunjukkan elemen ketergantungan pada ciri industri tradisional. Faktor lokasi yang paling berpengaruh adalah faktor aksesibilitas terhadap potensi lokal dan faktor akses terhadap jaringan bisnis.
\end{abstract}

\section{Kata kunci: Preferensi lokasi, faktor lokasi, industri berbasis potensi lokal (IBPL), karakteristik industri, persebaran lokasi industri}

Abstract: Locations for industrial development in Indonesia often determined by spatial allocation policies than the needs of industrial players. This creates a gap between the industrial spatial allocation stated in regulation and location needs of industrial actors. That indicated by the rejection of offerings location by industrial actors. The industry is a business activity and its location chosen in the most favourable place and influenced by the location factors. However, industrial location decisions not only emphasizes to the preferences of the perpetrators but also influenced by strategies and policies within the larger organizational environment of central and local governments. A quantitative approach used in this study to assess the location preferences of local-based industries (IBPL) in Banyumas Regency, Central Java Province, Indonesia. The objective is to evaluate the local spatial regulation of industrial allocation zones so that the gap can be reduced. The study findings revealed that IBPL site preferences related to the local content of industrial characteristics and industrial scales. Medium and large IBPLs indicated to clustered; their location preferences tend

\footnotetext{
1 Dinas Perumahan dan Kawasan Permukiman Kabupaten Banyumas

2 Departemen Perencanaan Wilayah dan Kota, UNDIP
} 
to close to the supplier industries and located in the main of roads. The spatial distribution of smallscales IBPL sites show the symptoms of spontaneous location. It influenced by factor of local potential accessibility of labor. There are ten location factors affecting IBPL site selection and lean to show the dependence element of traditional industry characteristics. The most influential location factors are accessibility to the local potencies and accessibility to the business networks.

Keywords: location preferences, location factors, local based industries (IBPL), industry characteristics, spatial distribution of industry

\section{PENDAHULUAN}

Terdapat dua aspek penting yang dipertimbangan dalam perencanaan dan pengembangan wilayah, yaitu aspek ekonomi dan aspek lokasi. Aspek ekonomi mempertimbangkan pemanfaatan sumberdaya atau potensi ekonomi secara efisien dan efektif (Rustiadi et al., 2009, pp. 15-17). Sementara aspek lokasi dipertimbangkan terkait aktivitas manusia atau ekonomi yang akan selalu terkait dengan lokasi. Pada aktivitas ekonomi seringkali ditemukan suatu kegiatan ekonomi hanya berlangsung pada lokasi tertentu tetapi tidak di lokasi yang lain (Harrington \& Warf, 1995, p. 6). Teori lokasi secara prinsip menekankan pada penjelasan tentang di mana aktivitas-aktivitas ekonomi berlangsung (Gorter \& Nijkamp, 2015, p. 287) serta mengkaji pola pemilihan lokasi oleh beberapa aktor berikut faktor-faktor lokasi yang mempengaruhinya. Lebih lanjut dikatakan oleh Gorter \& Nijkamp (2015), keputusan lokasi merupakan produk akhir yang interaktif, tampak sebagai pola teratur (regularities), melibatkan lebih dari satu aktor, dan dipengaruhi oleh keputusan lokasi sebelumnya.

Industri merupakan salah satu sektor ekonomi potensial yang dikembangkan dalam perencanaan daerah. Lokasi bagi pengembangan industri dapat dilihat dari dua sisi, pertama dari sudut pandang penawaran melalui kebijakan pemerintah dan kedua dari sudut pandang kebutuhan pelaku industri. Lokasi dari sisi kebijakan merupakan ruang industri yang ditawarkan pemerintah/ pemerintah setempat, berupa peruntukan industri dalam regulasi rencana tata ruang wilayah (RTRW). Sementara lokasi dari sisi kebutuhan industri merupakan kebutuhan yang bersifat mutlak untuk menjalankan aktivitas produksi. Tanpa lokasi atau lahan maka tidak ada sesuatu yang dapat diproduksi (Needham et al., 2013, p. 231) dan pada aktivitas bisnis industri, pelaku industri akan mencari lokasi di manapun di permukaan bumi yang paling menguntungkan (Elliott, 1948, p. 283). Pemilihan lokasi industri tidak hanya menekankan pada preferensi personal dari pelaku industri (Chapman \& Walker, 1991). Hal tersebut dipengaruhi pula oleh strategi dalam lingkungan organisasi besar termasuk birokrasi pemerintah pusat dan daerah. Sehingga, pemilihan lokasi tidak bisa ditentukan dari satu sisi saja, namun menuntut keselarasan antara dua sudut pandang lokasi tersebut.

Penelitian ini dilatarbelakangi adanya kesenjangan antara kebijakan dan kebutuhan lokasi bagi aktivitas produksi IBPL di Kabupaten Banyumas, Provinsi Jawa Tengah. Penelitian ini menggunakan pendekatan kuantitatif untuk mengkaji preferensi lokasi IBPL dan bertujuan untuk mengevaluasi kebijakan alokasi ruang setempat, sehingga kesenjangan antara dua sisi kebijakan dan kebutuhan lokasi industri dapat dikurangi. Penelitian ini memuat sasaran: 1) identifikasi karakteristik dan pola persebaran industri, 2) identifikasi faktor lokasi yang berpengaruh, dan 3) identifikasi pengaruh kebijakan alokasi ruang industri terhadap pemilihan lokasi industri oleh pelaku IBPL. Penelitian ini dibatasi pada jenis industri pengolahan dengan sumber bahan baku dari hasil pertanian dan hasil kehutanan (IHPK) dan karakteristiknya meliputi: asal bahan baku, tujuan pemasaran, dan asal tenaga kerja.

Penelitian ini menawarkan kajian yang belum banyak dibahas dalam literatur tentang lokasi industri, terkait pola persebaran industri yang menunjukkan gejala lokasi spontan. Gejala dimaksud dijelaskan Djojodipuro (1992) sebagai fenomena lokasi aktivitas produksi 
yang muncul di lokasi pelaku awal (inisiator) dan diikuti oleh industri sejenis sehingga menimbulkan aglomerasi di suatu kawasan/ wilayah tertentu, sementara faktor-faktor lokasi yang mempengaruhinya belum dikaji secara mendalam.

\section{Perkembangan Paradigma Teori Lokasi Industri}

Teori lokasi tidak hanya membahas lokasi industri (Fischer \& Nijkamp, 2014), namun termasuk di dalamnya lokasi fasilitas, permukiman, interaksi spasial, serta aglomerasi. Prinsip penentuan lokasi aktivitas ekonomi dijabarkan pada tujuan atau motivasi kegiatan (Gorter \& Nijkamp, 2015, pp. 287-288, Fischer \& Nijkamp, 2014). Prinsip kenyamanan dan aksesibilitas terhadap fasilitas umum dibutuhkan dalam menentukan lokasi tempat tinggal dan prinsip keuntungan adalah prioritas utama aktivitas bisnis seperti industri.

Lokasi industri merupakan tempat berlangsungnya aktivitas yang memfokuskan pada produksi komoditas untuk selanjutnya dijual ke pasar (Harrington \& Warf, 1995, p.2) dan dipengaruhi oleh motivasi utama pelaku untuk mendapatkan keuntungan serta pemilihannya merupakan konsekuensi yang tidak dapat ditarik kembali dan berorientasi jangka panjang (Szymanska \& Plaziak, 2014, p. 14). Faktor lokasi industri mendasarkan pada referensi teori lokasi industri yang berkembang sampai dengan saat ini.

\section{Teori Pendekatan Biaya Minimum dan Keuntungan Maksimal}

Lokasi aktivitas ekonomi pada mulanya dikenalkan oleh von Thunen dari pengamatan aktivitas pertanian di Jerman pada awal abad 19 (Jovanovic, 2003, p. 63) dan menjelaskan tipe penggunaan lahan konsentris sesuai jenis produksi. Teori ini disebut teori daerah lokasi (Djojodipuro, 1992, p. 5) dan pondasi pengetahuannya berpengaruh bagi pengembangan teori lokasi industri selanjutnya (Fujita, 2010, p. 4). Teori lokasi industri modern dikemukakan Alfred Weber (1909), didasarkan pada asumsi sifat ubiquitos sumber daya alam namun tidak untuk tenaga kerja, wilayah terisolasi dan homogen, serta persaingan sempurna pasar. Weber menekankan biaya transportasi minimun sebagai faktor utama penentuan lokasi (Rustiadi et al., 2009, p. 77, Chan, 2011, p. 9) dan dipengaruhi oleh indeks material (IM). Faktor tenaga kerja dan aglomerasi dapat memodifikasi lokasi atas dasar analisis lokasi biaya minimum sebelumnya (Songmei, 2005, p. 7), terkait dengan upah tenaga kerja dan keuntungan lokasi karena aglomerasi (Chapman \& F Walker, 1991).

Asumsi persaingan sempurna pasar Weber dianggap mengabaikan aspek dinamis dalam perubahan distribusi pendapatan atau disebut sebagai "static nature" (Capello, 2014, p. 524) berbeda dengan Hotelling (1929) yang mengemukakan lokasi terbaik memiliki sifat saling ketergantungan lokasional antar industri. Selanjutnya, August Losch (1954) memadukan melalui pendekatan lokasi yang memaksimalkan keuntungan dengan berorientasi pada pasar dan Melvin Greenhut (1956) melalui pendekatan pendekatan biaya minimum dan ketergantungan lokasi. Lokasi produksi optimum cenderung berada di dekat pasar dan keuntungan maksimal diperoleh dari selisih keuntungan dari hasil pengurangan total penerimaan (TR) terhadap biaya rata-rata (AC) paling tinggi (Smith, 1966, p. 99).

\section{Teori Pendekatan Perilaku Organisasi}

Pendekatan perilaku organisasi dalam pemilihan lokasi industri berkembang sebagai respon atas kecenderungan peran organisasi pada pengambilan keputusan lokasi (Chapman \& F Walker, 1991). Pendekatan ini didorong oleh fenomena de-industrialisasi di negara barat pada kurun waktu 1960-1980an (Gatfield \& Yang 2006, p. 49). Keputusan lokasi optimum dinyatakan sebagai proses pengambilan keputusan perusahaan dan dipengaruhi oleh faktor eksogen dan endogen. Faktor eksogen terkait dengan biaya dan faktor endogen berasal dari struktur organisasi dan peran pengambil keputusan perusahaan (Gatfield \& Yang, 2006, p. 51; Szymanska \& Plaziak, 2014, p. 15). 
Pendekatan terhadap perilaku organisasi dianggap masih mendasarkan analisis yang digunakan pada penentuan lokasi industri manufaktur tradisional (Gatfield \& Yang, 2006, p. 48) dan dianggap masih memandang hubungan antara karakteristik organisasi dan lingkungan produksi bersifat statis, bukan dinamis (Assink et al., 2009, p. 4). Permasalahan utama teori ini terkait dengan apa yang disebut "black box" (Pen, 1999 dan Yang et al., 2006). Didefinisikan sebagai komponen sistem yang tidak diketahui strukturnya (Dicken \& Lloyd, 1990 dalam Pen, 1999) serta terkait dengan antribut di dalam organisasi itu sendiri. Pengaruhnya kemungkinan karena dominasi intervensi dari pembuatan keputusan, sebagaimana dibuktikan Cees-Jan Pen (1999), bahwa dalam perspektif perilaku organisasi, faktor personal memiliki kepentingan yang sama dengan faktor penentu kecenderungan relokasi industri.

\section{Arah Baru Pendekatan Lokasi Industri}

Pengaruh perkembangan teknologi dan informasi serta globalisasi seolah-olah meniadakan batas-batas administratif (Assink et al., 2009, p. 4) dan dianggap kematian terhadap jarak (the death of distance). Pendekatan jaringan bisnis yang komprehensif lebih ditekankan dan tercermin dari peningkatan industri menggunakan tenaga kerja terampil yang berbasiskan teknologi (Yang et al., 2006, p. 49). Teknologi, inovasi, dan kreatifitas melahirkan ekonomi kreatif (Florida, 2001 dalam Gorter \& Nijkamp, 2015, p. 291), digerakkan oleh tenaga kerja terdidik dan terampil (Florida, 2001 dalam Assink et al., 2009, p. 6), dan mengasilkan inovasi teknologi dan arah baru industri dalam hal produksi (Hall, 2000, p. 639). Fenomena ekonomi kreatif di negara-negara maju yang notabene dikatakan mengalami de-industrialisasi berlawanan dengan yang terjadi di negara berkembang, khususnya Indonesia yang masih dalam proses industrialisasi. Ekonomi kreatif di Indonesia memiliki karakteristik sebagai industri kreatif yang disebut sebagai industri budaya tradisional (Fahmi et al., 2016).

Perbedaan konsep pendekatan pada perkembangan teori lokasi industri, tidak berarti konsep yang lebih baru mengeliminir konsep yang terdahulu. Namun, lebih menguatkan dengan asumsi-asumsi baru yang disesuaikan oleh perubahan kondisi yang lebih kompleks serta tergantung dari tipe bisnis yang dijalankan (Szymanska \& Plaziak, 2014). Hasil studi empiris membuktikan bahwa pendekatan teori klasik masih tetap diacu sebagai pendekatan normatif dalam pemilihannya (Kimelberg \& Nicoll, 2012). Penelitian terhadap industri manufaktur di Kawasan Metropolitan Seoul menunjukkan bahwa faktor lokasi tradisional atau yang sering disebut sebagai hard factors masih merupakan variabel yang berpengaruh (An, Kang, and Lee, 2014). Kriteria pasar tenaga kerja, pasar produk, dan biaya produksi masih dipertimbangkan sebagai sebagai faktor penting untuk menentukan lokasi aktivitas produksi industri konstruksi di Polandia (Szymanska \& Plaziak, 2014) dan pengembangan industri yang berbasis produk pertanian lokasi industri gula dan etanol di Brazil masih menekankan kedekatannya pada sumber input (Bargos et al., 2016).

\section{Distribusi Spasial Lokasi Industri}

Persebaran lokasi industri menunjukkan pola tertentu atau "regularities". Aktivitas ekonomi seperti halnya industri akan cenderung berkumpul secara geografis atau beraglomerasi (McCann \& Folta, 2008) untuk akan mendapatkan keuntungan eksternalitas. Efisiensi melalui pemilihan biaya terendah proses produksi atau biaya angkutan masih menjadi hal utama yang dipertimbangkan (Djojodipuro, 1992, p. 179). Kematian terhadap jarak tidak mutlak berlaku pada seluruh aktivitas ekonomi atau industri, terlihat pada tiga pola persebaran aktivitas produksi terkait aglomerasi ekonomi (kota) di Spanyol sebagai representasi jarak (Polèse et al., 2007). Pertama, aktivitas jasa cenderung dipengaruhi oleh ukuran kota untuk mendapatkan akses maksimal pasar dan jarak menjadi penting. Kedua, 
industri primer dan berbasis bahan baku berada pada lokasi yang lebih jauh atau berada pada kota yang kecil dan dekat dengan bahan baku. Ketiga, industri manufaktur lebih memilih pada kota-kota medium namun berada dekat dengan kota utama atau metropolitan area. Batas jarak satu jam perjalanan dipertimbangkan untuk tetap terhubung langsung (face to face contact) dengan penyedia jasa di metopolitan area.

Selain disebabkan oleh kemungkinan keuntungan eksternalitas, aglomerasi industri terjadi karena gejala lokasi spontan yang dijelaskan sebagai fenomena industri yang muncul dan berada pada lokasi pemiliknya (Djojodipuro, 1992, p. 188). Dicontohkan gejala ini terjadi di Indonesia pada perkembangan Pabrik Rokok Djarum di Kudus dengan inovator Nitisemito. Lokasi spontan industri ini dianggap berhasil dan menarik aktor lain sehingga menimbulkan aglomerasi industri pada bidang yang sama.

\section{Faktor-Faktor Penentu Lokasi Industri}

Faktor-faktor lokasi sebagai pertimbangan dalam pemilihan lokasi dianggap bersifat dinamis. Keputusan lokasi dapat dipengaruhi oleh berbagai pertimbangan penting yang sangat dibatasi oleh skala geografis (Chapman \& F Walker, 1991, p. 50). Usaha untuk mensintesakan secara sistematis faktor-faktor lokasi yang dapat berlaku umum pada pemilihan lokasi industri belum pernah ditemukan (Badri, 2007). Penelitian ini menggunakan 33 variabel lokasi yang dapat disintesakan dari review literature dan mengacu pada faktor lokasi tradisional jarak bahan baku, pasar, tenaga kerja, transportasi (Djojodipuro, 1992; Polèse et al., 2007; Kimelberg \& Nicoll, 2012; dan Bargos et al., 2016), struktur organisasi perusahaan (Gatfield \& Yang, 2006 dan Szymanska \& Plaziak, 2014), dan variabel pada industri baru yang berkembang (newly emerging industries) (Gatfield \& Yang, 2006). Faktorfaktor lokasi tersebut meliputi : x1) kepemilikan, x2) tipe industri, x3) struktur perusahaan, $\mathrm{x} 4$ ) tipe keputusan lokasi, $\mathrm{x}$ 5) jarak terhadap tempat tinggal pemilik, $\mathrm{x} 6$ ) asal bahan baku, $\mathrm{x} 7$ ) suplayer, $\mathrm{x} 8$ ) biaya pengangkutan bahan baku, x9) letak pasar, x10) biaya pengangkutan ke pasar, $\mathrm{x} 11$ ) upah tenaga kerja, $\mathrm{x} 12$ ) pendidikan tenaga kerja, $\mathrm{x} 13$ ) tenaga kerja terlatih, $\mathrm{x} 14$ ) industri sejenis, x15) kolaborasi dengan industri lokal/ regional, x16) insentif pajak, x17) kemudahan perizinan, $\mathrm{x} 18$ ) perkembangan teknologi informasi, x19) dekat dengan pemegang kekayaan intelektual, x20) kesempatan berkolaborasi dengan R \& D, x21) kesempatan berkolaborasi dengan lembaga pendidikan dan riset, $\mathrm{x} 22$ ) harga lahan/ sewa lahan, x23) kondisi fisik lahan, x24) area untuk ekspansi bisnis, x25) kewajiban pengelolaan limbah, x26) iklim bisnis, x27) jaringan jalan utama, x28) air bersih, x29) jaringan energi, x30) jaringan telekomunikasi, x31) aksesibilitas terhadap transportasi umum, x32) jarak terhadap CBD, dan x33) biaya hidup dan fasilitas kenyamanan.

\section{Kebijakan dan Alokasi Ruang Industri}

Ruang industri sesuai ketentuan Undang-Undang Republik Indonesia Nomor 26 Tahun 2007 (UUPR) tentang Penataan Ruang, disusun dalam pola ruang atau distribusi pemanfaatan ruang untuk fungsi lindung dan fungsi budidaya. KPI dalam UUPR merupakan bagian kawasan budidaya dan disusun hierarkis dalam peraturan perundang-undangan tentang RTRW dari tingkat nasional, provinsi, dan kabupaten/kota. Kebijakan alokasi ruang industri di Kabupaten Banyumas disusun dalam peraturan daerah tentang RTRW melalui Peraturan Daerah Nomor 10 Tahun 2011. Substansi ketentuannya berisi alokasi ruang industri dalam KPI yang diatur untuk klasifikasi industri besar, menengah, industri kecil. KPI ini meliputi dua kriteria, pertama berupa delineasi zona dan kedua berupa arahan umum kegiatan industri. Ketentuan kebijakan ruang industri yang dimaksud adalah: kebijakan 1) industri boleh berlokasi di perkotaan dengan syarat tidak menghasilkan limbah B3 (bahan beracun berbahaya); kebijakan 2) Industri boleh berlokasi dekat dengan bahan baku, dan 
kebijakan 3) industri besar dan menengah diarahkan berlokasi pada peruntukan tertentu atau KPI.

\section{METODE}

Kerangka konsep penelitian ini dijabarkan dalam bentuk hubungan antar dua variabel kunci yang mempengaruhi kesesuaian lokasi industri di wilayah studi (Gambar 1). Sebagai aktivitas ekonomi, lokasi industri dilihat dari perspektif bisnis yang didasarkan pada efisiensi. Namun demikian, dalam perkembangan lingkungan sosial ekonomi yang dinamis, pemilihan lokasi industri melibatkan organisasi besar, dalam hal ini organisasi pemerintah/ Pemda. Kesesuaian dapat dicapai bila perangkat kebijakan dari organisasi pemerintah merepresentasikan preferensi pelaku industri terhadap lokasi produksinya.



\section{Gambar 1. Kerangka Konsep Penelitian}

Penelitian ini dilakukan terhadap 165 sampel pelaku IBPL. Sampel berasal dari data populasi industri pengolah hasil pertanian dan kehutanan (IHPK) Tahun 2015 yang berjumlah 31.682 unit usaha. Sampel ditentukan sebesar 165 terkait metode analisis faktor yang digunakan, dalam hal ini sampel minimum sebesar lima kali jumlah variabel penelitian (Streiner, 1994 dalam Hatcher \& O’Rourke, 2013, p. 9). Teknik pengambilan sampel menggunakan probability sampling, didistribusikan dengan metode disproportionate stratified random sampling (Sugiyono, 2016). Sampel dibedakan atas klasifikasi skala industri dan didistribusikan sesuai kelompok industri pengolah hasil pertanian dan kehutanan. Jumlahnya meliputi dua sampel industri besar, 16 sampel industri menengah pengolah hasil pertanian, 16 sampel industri menengah pengolah hasil kehutanan, dan 161 sampel industri kecil. Selanjutnya sampel industri kecil didistribusikan pada kelompok industri getuk goreng (5), tepung aci/ tapioka (15), emping melinjo (15), keripik pisang dan ubi-ubian (5), klanting/ cantir (5), penyulingan minyak atsiri (5), pengolahan kayu (15), pengolahan bambu (15), tahu/ tempe (15), dan gula kelapa (26).

Data penelitian berupa data primer dan sekunder. Data primer diperoleh melalui kuesioner, observasi, dan pemetaan, sedangkan data sekunder diperoleh dari statistika daerah dan sumber lain di Pemda. Karakteristik industri dianalisis melalui metode statistika deskriptif dan pemetaan. Distribusi spasial industri menengah besar dianalisis melalui 
metode nearest neighbour dengan software ArcGIS 10, sementara persebaran industri kecil dipetakan dari konversi data tabel. Selanjutnya, faktor lokasi yang mempengaruhi dianalisis dengan metode analisis faktor, sementara pengaruh kebijakan alokasi ruang menggunakan metode skoring atau pembobotan.

\section{HASIL DAN PEMBAHASAN}

\section{Karakteristik IBPL dan Persebaran Lokasinya}

Karakteristik usaha IBPL berkaitan dengan ketergantungan industri terhadap inputoutput produksinya. Keterkaitan ini mengindikasikan karakteristik muatan potensi lokal dari tiap jenis industri yang menunjukkan kecenderungan konten lokal yang digunakan dalam aktivitas produksinya (Tabel 1). Karekteristik lokal tersebut mempengaruhi lokasi produksi industri dan pengelompokannya. Aglomerasi terjadi setidaknya karena keterkaitan antar industri, terhadap bahan baku atau tenaga kerja, dan akses pasar.

Tabel 1. Karakteristik Lokal dan Preferensi Lokasi IBPL

\begin{tabular}{|c|c|c|c|}
\hline Kategori & Skala dan Jenis Industri & $\begin{array}{l}\text { Karakteristik Lokal } \\
\text { Industri }\end{array}$ & Preferensi Lokasi \\
\hline Kategori I & $\begin{array}{l}\checkmark \text { Industri besar } \\
\text { pengolahan hasil } \\
\text { pertanian/ minyak } \\
\text { atsiri } \\
\checkmark \text { Industri besar } \\
\text { pengolahan kayu }\end{array}$ & $\begin{array}{l}\text { Karakteristik lokal yang } \\
\text { kuat berasal dari asal } \\
\text { bahan baku yang } \\
\text { diperoleh dari industri } \\
\text { pemasok lokal sejenis. }\end{array}$ & $\begin{array}{l}\checkmark \text { lokasi mendekati dan } \\
\text { beraglomerasi dengan industri } \\
\text { pemasok eksisting } \\
\checkmark \text { berada pada jalur aksesibilitas } \\
\text { utama regional }\end{array}$ \\
\hline Kategori II & $\begin{array}{l}\checkmark \text { Industri menengah } \\
\text { pengolahan kayu } \\
\checkmark \text { Industri menengah } \\
\text { pengolahan hasil } \\
\text { pertanian }\end{array}$ & $\begin{array}{l}\text { Karakteristik lokal yang } \\
\text { kuat berasal dari tenaga } \\
\text { kerja lokal dan } \\
\text { ketergantungan bahan } \\
\text { baku dari industri } \\
\text { pemasok lokal. }\end{array}$ & \\
\hline Kategori III & $\begin{array}{l}\checkmark \text { Industri kecil gula } \\
\text { kelapa }\end{array}$ & $\begin{array}{l}\text { Karakteristik lokal yang } \\
\text { kuat berasal dari bahan } \\
\text { baku, tenaga kerja } \\
\text { setempat, dan produk } \\
\text { untuk pasar domestik. } \\
\text { Karakteristik ini tidak } \\
\text { lepas dari sifat bahan } \\
\text { baku dan kedekatan } \\
\text { lokasi produksi } \\
\text { terhadap bahan baku. }\end{array}$ & $\begin{array}{l}\checkmark \text { lokasi mendekati dan } \\
\text { beraglomerasi pada sumber } \\
\text { bahan baku utama, dan } \\
\text { menunjukkan gejala lokasi } \\
\text { spontan. } \\
\checkmark \text { berada di kawasan permukiman } \\
\text { menjadi satu dengan hunian/ } \\
\text { rumah tinggal }\end{array}$ \\
\hline Kategori IV & $\begin{array}{l}\checkmark \text { Industri kecil Klanting/ } \\
\text { Cantir } \\
\checkmark \text { Industri kecil Emping } \\
\text { Melinjo } \\
\checkmark \text { Industri kecil Tahu/ } \\
\text { Tempe }\end{array}$ & $\begin{array}{l}\text { Karakteristik lokal yang } \\
\text { kuat berasal dari asal } \\
\text { bahan baku, tenaga } \\
\text { kerja, proses produksi, } \\
\text { dan pasar produk. }\end{array}$ & \\
\hline Kategori V & $\begin{array}{l}\checkmark \text { Industri kecil Getuk } \\
\text { Goreng } \\
\checkmark \text { Industri kecil Keripik } \\
\text { Pisang dan ubi-ubian } \\
\checkmark \text { Industri kecil } \\
\text { Pengolahan Bambu }\end{array}$ & $\begin{array}{l}\text { Karakteristik lokal yang } \\
\text { kuat berasal dari tenaga } \\
\text { kerja industri dan } \\
\text { produk spesifik yang } \\
\text { menjadi brand lokasi } \\
\text { pengelompokannya. }\end{array}$ & $\begin{array}{l}\checkmark \text { aglomerasi menunjukkan gejala } \\
\text { lokasi spontan. Dipengaruhi } \\
\text { oleh tenaga kerja serta } \\
\text { lingkungan usaha industri yang } \\
\text { memiliki brand image lokal } \\
\checkmark \text { berada di kawasan permukiman } \\
\text { menjadi satu dengan hunian/ } \\
\text { rumah tinggal dan pada industri } \\
\text { getuk goreng sekaligus menjadi } \\
\text { outlet penjualan }\end{array}$ \\
\hline Kategori VI & $\begin{array}{l}\checkmark \text { Industri kecil Tepung } \\
\text { Aci/ Tapioka }\end{array}$ & $\begin{array}{l}\text { Karakteristik lokal yang } \\
\text { kuat berasal dari }\end{array}$ & $\begin{array}{l}\checkmark \text { aglomerasi menunjukkan gejala } \\
\text { lokasi spontan. Dipengaruhi }\end{array}$ \\
\hline
\end{tabular}




\begin{tabular}{|c|c|c|c|}
\hline Kategori & Skala dan Jenis Industri & $\begin{array}{c}\text { Karakteristik Lokal } \\
\text { Industri }\end{array}$ & Preferensi Lokasi \\
\hline & $\begin{array}{l}\checkmark \text { Industri kecil } \\
\text { Penyulingan Minyak } \\
\text { Atsiri } \\
\checkmark \text { Industri kecil } \\
\text { Pengolahan Kayu }\end{array}$ & $\begin{array}{l}\text { tenaga kerja industri } \\
\text { dan potensi pasar lokal } \\
\text { untuk bertindak sebagai } \\
\text { pemasok }\end{array}$ & $\begin{array}{l}\text { oleh tenaga kerja serta } \\
\text { lingkungan usaha industri } \\
\text { spesifi sertamemiliki keterkaitan } \\
\text { dengan industri besar dan } \\
\text { menengah } \\
\checkmark \text { berada di kawasan permukiman } \\
\text { terpisah dari hunian namun } \\
\text { ralatif dekat dengan tempat } \\
\text { tinggal pemilik. }\end{array}$ \\
\hline
\end{tabular}

Sumber: Penulis, 2017

Tabel 1, karakteristik konten lokal IBPL dikategorikan dalam enam kategori. Kategori I dan II, merupakan industri yang memiliki ketergantungan tinggi terhadap industri sejenis yang menjadi suplayer input produksinya. Termasuk dalam kategori ini industri skala besar dan menengah dan memiliki kecenderungan mengelompok. Hal tersebut diketahui dari hasil analisis nearest neighbour dengan nilai p-value 0,044516 dan z-score -2,009199. Skor tersebut menunjukkan nilai pada rentang yang signifikan menolak hipotesis nol $\left(\mathrm{H}_{0}\right)$ dengan pola sebaran clustered. Keterkaitan antar industri sejenis pada kategori ini menyebabkan lokasi produksi mendekat dan beraglomerasi pada lokasi industri eksisting. Aglomerasi terjadi karena kebutuhan untuk mendapatkan kemudahan bahan baku dengan mengurangi jarak, sehingga dapat diperoleh lebih murah dan kestabilan pasokannya dapat terjaga. Keterkaitan industri besar dan menengah terhadap industri lain sejenis diilustrasikan pada Gambar 2. Pada gambar tersebut terlihat industri besar dan menengah pengolahan kayu beraglomerasi di sekitar lokasi industri sejenis eksisting (termasuk industri kecil) dan berada pada jalur utama pergerakan regional.



Sumber: Bappeda Kabupaten Banyumas dan hasil survei primer, diolah, 2017

\section{Gambar 2. Distribusi Spasial IBPL Sesuai Karakteristik Lokal}

Catatan khusus IBPL pada kategori I dan II pada industri besar pengolahan minyak atsiri dan industri menengah pengolahan kayu (suplayer). Industri besar minyak atsiri 
walaupun sebagian besar tidak bergantung dari suplayer lokal, namun lokasi produksinya memiliki nilai historis sebagai lokasi industri perintis. Sementara industri menengah pengolahan kayu tidak hanya berorientasi sebagai pemasok industri sejenis di lokal kabupaten, dengan pertimbangan resiko keuangan dan manajemen cashflow perusahaan. Pelaku industri lebih memilih menjual produknya pada industri yang dapat melakukan pembayaran dengan jangka waktu yang relatif cepat, walaupun jaraknya lebih jauh di luar kabupaten dan margin keuntungan yang diperoleh lebih rendah.

Kategori III dan IV pada Tabel 1 merupakan industri yang memiliki konten lokal yang paling kuat di wilayah studi dan seluruhnya termasuk industri skala kecil. Industri pada kedua kategori ini memiliki perbedaan karakteristik persebaran lokasi yang terkait dengan aglomerasi. Aglomerasi pada industri di kategori III yang didominasi industri kecil gula kelapa, bersifat bukan sebagai kebutuhan untuk mendapatkan keuntungan aglomerasi. Pengelompokan terjadi karena pengaruh bahan baku dan gejala lokasi spontan (Gambar 2). Bahan baku berasal dari sumber tanaman perkebunan yang tersebar di lokal kabupaten dan bersifat perishable sehingga harus diolah di dekat sumbernya. Sementara gejala lokasi spontan terjadi karena replikasi usaha sejenis yang dipengaruhi oleh tenaga kerja industri dengan karakteristik keterampilan usaha yang diperoleh turun-temurun atau ada dan bersifat spesifik pada masyarakat perdesaan.

Industri kategori IV memiliki konten lokal kuat dari keberadaan bahan baku dan tenaga kerja industri. Industri ini pada dasarnya mudah direplikasi pada lokasi lain, namun potensi terjadinya aglomerasi industri tidak berada di setiap tempat. Aglomerasi hanya terjadi pada kawasan tertentu yang masyarakatnya memiliki indentitas sebagai "pengrajin" dari produk industri ini dan menunjukkan gejala lokasi spontan (Gambar 2). Aglomerasi industri ini disebabkan oleh replikasi industri yang berasal dari faktor tenaga kerja yang awal mulanya bekerja pada industri sejenis. Pelaku industri ini memisahkan diri dan mendirikan industri yang sama pada lokasi di sekitar industri pionirnya, sehingga terbentuk aglomerasi industri.

Masih pada Tabel 1, industri pada kategori $\mathrm{V}$ merupakan industri kecil yang berorientasi pada keterampilan tenaga kerja industri atau pasar industri yang menjadi identitas tertentu dari produk. Bahan baku industri dapat diperoleh dari mana saja baik lokal maupun luar kabupaten, ketergantungan lokasi utama berasal dari proses produksi pada lokasi spesifik dan pasar produk yang telah memiliki brand lokasi. Aglomerasi terjadi di sekitar industri yang menjadi inisiatornya dan menunjukkan gejala lokasi spontan (Gambar 2). Tipe aglomerasi industri yang dibutuhkan oleh jenis industri ini, berhubungan dengan keberadaan tenaga kerja spesifik (kerajinan bambu) dan pasar produk yang berada pada lokasi produksi (brand lokasi).

Kategori VI pada Tabel 1 merupakan tipe industri-industri kecil yang bertindak sebagai industri suplayer industri sejenis di lokal dan di luar kabupaten. Hubungan tersebut tampak sebagai keterkaitan ke depan/forward linkage terhadap industri besar dan menengah yang menjadi tujuan pemasarannya, sebagaimana dijelaskan pada Kategori I dan II. Industri pada kategori ini berkembang dan beraglomerasi pada lokasi yang memiliki tenaga kerja spesifik di lokasi dimana awal mula industri ini berkembang dan menunjukkan gejala lokasi spontan (Gambar 2). Replikasi usaha industri sama halnya dengan yang terjadi pada industri kategori IV.

\section{Faktor-faktor Lokasi yang Berpengaruh}

Hasil analisis faktor menunjukkan bahwa dari nilai eigenvalues yang ditetapkan 1, terdapat kemungkinan 10 komponen yang terbentuk, dengan nilai varians yang dapat dijelaskan oleh kesepuluh komponen terbentuk ini adalah $74,077 \%$. Selanjutnya dari hasil proses rotasi faktor (Table 2) diperoleh 10 komponen beserta variabel anggotanya yang kemudian diberikan penamaan baru pada komponen yang terbentuk (Tabel 3). Faktor lokasi 
yang paling berpengaruh dengan nilai eigenvalue dua tertinggi (5,581 dan 4,394) yakni: 1$)$ faktor aksesibilitas terhadap potensi lokal dan 2) faktor akses terhadap jaringan bisnis. Sementara kedelapan faktor yang lain adalah: 1) modal finansial pengusaha, 2) pendukung proses produksi dan potensi pemasaran, 3) keuntungan aglomerasi, 4) keterampilan tenaga kerja dan pengolahan limbah, 5) brand image, 6) riset pengembangan terhadap ketersediaan bahan baku; 7) tingkat pendidikan dan standar hidup tenaga kerja; dan 8) regulasi pemerintah.

Tabel 2. Rotated component matrix

\begin{tabular}{|c|c|c|c|c|c|c|c|c|c|c|}
\hline \multicolumn{11}{|l|}{ Rotated Component Matrix ${ }^{a}$} \\
\hline & \multicolumn{10}{|c|}{ Component } \\
\hline & 1 & 2 & 3 & 4 & 5 & 6 & 7 & 8 & 9 & 10 \\
\hline jarak terhadap tempat tinggal &,- 800 & 075 &,- 064 &,- 034 &,- 016 &,- 080 &,- 001 &,- 061 &,- 259 & 298 \\
\hline dekat jaringan jalan utama &, 735 & ,294 &, 053 &, 001 &,- 018 &, 216 &, 196 &,- 238 &, 061 &, 067 \\
\hline suplayer & ,649 &,- 064 &,- 006 &,- 069 &, 048 &,- 232 & ,270 & ,089 &,- 080 & ,367 \\
\hline tipe industri & ,641 &,- 034 &, 113 & ,259 & ,190 &,- 328 &, 136 &,- 050 &,- 315 &, 100 \\
\hline area untuk ekspansi bisnis & ,631 &, 036 & ,379 &, 263 &,- 073 &,- 086 &, 030 &, 013 &,- 282 &, 054 \\
\hline $\begin{array}{l}\text { aksesibilitas } \quad \text { transportasi } \\
\text { umum }\end{array}$ &, 081 & ,827 &, 058 &,- 187 &,- 128 &,- 060 &, 216 & ,028 & ,021 &,- 011 \\
\hline $\begin{array}{l}\text { perkembangan teknologi } \\
\text { informasi }\end{array}$ & ,029 & ,798 &,- 148 & ,308 &, 060 &,- 118 &,- 152 &, 007 &, 010 &, 128 \\
\hline jarak terhadap CBD &,- 214 &, 559 & 099 & ,141 & 059 &, 024 & ,198 &,- 195 & ,398 &, 137 \\
\hline tipe keputusan lokasi & ,364 &, 503 &,- 162 &, 045 & 295 & 260 & 251 & ,225 & 097 & 230 \\
\hline kondisi fisik lahan & ,094 &,- 082 & ,768 & ,077 & ,273 & ,104 & ,264 &,- 212 &,- 163 & ,053 \\
\hline harga lahan/ sewa lahan &, 176 &, 070 & 695 & ,202 & ,345 &,- 224 & ,066 &,- 129 &,- 089 &, 054 \\
\hline $\begin{array}{l}\text { biaya pengangkutan bahan } \\
\text { baku }\end{array}$ & ,048 &,- 253 & 679 & ,391 &,- 126 &,- 035 &,- 103 &, 158 &, 025 &, 015 \\
\hline struktur perusahaan &, 212 & ,228 & ,452 &,- 101 &, 147 & ,193 &, 007 &, 168 &, 059 &,- 448 \\
\hline upah tanaga kerja & ,052 &, 184 & ,038 &, 779 & ,083 & ,162 & ,086 & ,085 & ,189 &, 110 \\
\hline terdapat jaringan air bersih &, 082 &,- 069 & ,309 &, 653 &, 030 &,- 214 &,- 087 &,- 030 & 137 &,- 015 \\
\hline letak pasar &,- 007 & ,306 &, 144 & ,638 & ,286 &, 034 &,- 003 &,- 054 &,- 225 &,- 305 \\
\hline biaya pengangkutan ke pasar & 131 &,- 381 &, 177 &, 559 & ,272 & 211 &, 135 & 011 & 057 &, 057 \\
\hline $\begin{array}{l}\text { kolaborasi dengan industri } \\
\text { lokal/ regional }\end{array}$ &, 145 &, 038 &, 015 & ,466 & 298 &, 361 &,- 201 &,- 239 &, 162 &, 311 \\
\hline terdapat jaringan energi &, 102 &,- 082 &, 117 &, 151 & ,768 &,- 131 & ,206 &,- 010 &, 055 &,- 161 \\
\hline $\begin{array}{l}\text { berkelompok dengan industri } \\
\text { sejenis }\end{array}$ &,- 175 &, 041 &,- 027 &, 161 & 627 &, 556 &,- 071 &,- 252 &,- 087 &,- 080 \\
\hline iklim bisnis & ,118 & ,195 & ,294 &, 066 & ,606 & ,256 &,- 272 & ,283 &,- 165 &,- 111 \\
\hline kepemilikan &,- 100 &,- 002 & 472 & ,233 &, 595 &,- 196 &,- 225 &,- 027 &, 056 &, 021 \\
\hline tenaga kerja terlatih &, 075 &,- 034 &,- 231 &, 111 &,- 073 & ,786 &, 125 &, 126 &, 083 &, 008 \\
\hline kewajiban pengelolaan limbah &, 192 &, 117 &,- 260 &, 065 &,- 011 &,- 670 & ,078 &,- 008 & ,224 & ,294 \\
\hline $\begin{array}{l}\text { dekat dengan pemegang } \\
\text { kekayaan intelektual }\end{array}$ &, 073 & 097 &,- 058 &,- 039 &, 046 &,- 034 & ,814 & ,093 &, 071 &,- 016 \\
\hline $\begin{array}{ll}\text { terdapat } & \text { jaringan } \\
\text { telekomunikasi } & \end{array}$ & ,298 & ,063 & ,202 &, 071 &,- 079 & ,088 & ,812 &,- 018 &,- 063 &, 009 \\
\hline asal bahan baku &,- 212 &,- 143 &,- 012 & 011 &,- 051 &, 047 & ,066 & ,828 &,- 037 & ,097 \\
\hline kolaborasi dengan $\mathrm{R} \& D$ & ,441 & ,362 &,- 041 &,- 008 &,- 033 &,- 082 &, 149 & ,609 &, 281 &,- 036 \\
\hline $\begin{array}{l}\text { kolaborasi dengan lembaga } \\
\text { pendidikan dan riset }\end{array}$ & ,222 &, 523 &,- 245 &, 001 & ,154 &, 163 &,- 171 &, 556 & ,363 &, 038 \\
\hline $\begin{array}{l}\text { biaya hidup dan fasilitas } \\
\text { pelayanan }\end{array}$ &,- 050 &, 007 &,- 145 &, 189 &,- 117 &,- 162 &,- 078 &,- 030 &, 734 &, 060 \\
\hline $\begin{array}{l}\text { tingkat pendidikan tenaga } \\
\text { kerja }\end{array}$ & ,070 &, 270 &, 049 & ,037 &, 147 &, 167 &, 172 & ,344 & ,642 &, 150 \\
\hline insentif pajak &, 002 &, 140 &, 031 &,- 032 &,- 190 &,- 112 &,- 056 & ,098 & ,085 & ,815 \\
\hline kemudahan perizinan & ,227 & ,320 & ,312 & ,145 & ,090 & ,060 & ,135 & ,106 & ,270 & ,523 \\
\hline $\begin{array}{l}\text { Extraction Method: Principal } \\
\text { Rotation Method: Varimax wit } \\
\text { a. Rotation converged in } 24 \text { ite }\end{array}$ & $\begin{array}{l}\text { mpone } \\
\text { Kaiser } \\
\text { tions. }\end{array}$ & nt Ana & sis. & & & & & & & \\
\hline
\end{tabular}

Sumber: Hasil analysis SPSS, 2017 


\section{Pengaruh Kebijakan Alokasi Ruang Terhadap Pemilihan Lokasi IBPL}

Kebijakan 1 tentang diperbolehkannya industri non-B3 di perkotaan, merupakan variabel yang memberikan pengaruh positif bagi pengusaha dalam memilih lokasi produksi dengan nilai rata-rata 2,824. Pengaruh ini dapat berarti bahwa ketentuan dimaksud tidak menghambat dan mempersulit pelaku industri untuk memilih lokasi aktivitas produksi. Kebijakan ini dipengaruhi oleh pelaku industri yang menganggap aktivitas industrinya tidak menghasilkan limbah B3, sehingga memungkinkan pengembangan di perkotaan untuk lokasi industri yang berfungsi utama sebagai perkantoran.

\section{Table 3. Penamaan Faktor Terbentuk}

\begin{tabular}{|c|c|}
\hline Komponen & Variabel \\
\hline $\begin{array}{l}\text { Komponen } \\
\quad 1\end{array}$ & $\begin{array}{l}\text { Komponen ini berisi } 5 \text { variabel, merepresentasikan pertimbangan terhadap akses potensi } \\
\text { dasar/ potensi pada diri pelaku usaha dan kondisi sekitar. Melalui pertimbangan tersebut } \\
\text { komponen ini dinamakan FAKTOR AKSESIBILITAS TERHADAP POTENSI LOKAL }\end{array}$ \\
\hline $\begin{array}{l}\text { Komponen } \\
\quad 2\end{array}$ & $\begin{array}{l}\text { Komponen ini berisi } 4 \text { variabel, menyatakan persepsi pelaku usaha terhadap lingkungan } \\
\text { bisnisnya, ketika akan menentukan tipe lokasi aktivitas produksinya. Oleh karenanya } \\
\text { komponen ini diberi nama FAKTOR AKSES TERHADAP JARINGAN BISNIS }\end{array}$ \\
\hline $\begin{array}{l}\text { Komponen } \\
\quad 3\end{array}$ & $\begin{array}{l}\text { Komponen ini berisi } 4 \text { variabel, merepresentasikan kemampuan mengakuisisi lahan dan } \\
\text { mengolahnya, serta terkait dengan kemampuan modal pengusaha, oleh karenanya faktor ini } \\
\text { bisa disebut FAKTOR MODAL FINANSIAL PENGUSAHA }\end{array}$ \\
\hline $\begin{array}{l}\text { Komponen } \\
\quad 4\end{array}$ & $\begin{array}{l}\text { Komponen ini berisi } 5 \text { variabel yang merepresentasikan kebutuhan inpututama produksi dan } \\
\text { potensi dari pasar yang bisa dijangkau, maka komponen ini dinamakan FAKTOR } \\
\text { PENDUKUNG PROSES PRODUKSI DAN POTENSI PEMASARAN }\end{array}$ \\
\hline $\begin{array}{l}\text { Komponen } \\
\quad 5\end{array}$ & $\begin{array}{l}\text { Komponen ini berisi } 4 \text { variabel yang merepresentasikan keuntungan untuk dekat dengan } \\
\text { industri sejenis dengan iklim bisnis yang dianggap nyaman, oleh karenanya faktor ini } \\
\text { dinamakan FAKTOR KEUNTUNGAN AGLOMERASI }\end{array}$ \\
\hline Komponen & Komponen ini terdiri dari 2 variabel yang merepresentasikan keterampilan tenaga kerja dan \\
\hline 6 & $\begin{array}{l}\text { kemampuan industri untuk mengolah limbah, sehingga dinamakan FAKTOR } \\
\text { KETERAMPILAN TENAGA KERJA DAN PENGELOLAAN LIMBAH }\end{array}$ \\
\hline $\begin{array}{l}\text { Komponen } \\
\quad 7\end{array}$ & $\begin{array}{l}\text { Komponen ini berisi } 2 \text { variabel yang merepresentasikan peluang keuntungan dan eksistensi } \\
\text { berada dekat dengan industri yang memiliki paten, sehingga bisa dinamakan FAKTOR } \\
\text { BRAND IMAGE }\end{array}$ \\
\hline $\begin{array}{l}\text { Komponen } \\
\quad 8\end{array}$ & $\begin{array}{l}\text { Faktor ini berisi } 3 \text { variabel yang merepresentasikan kesinambungan ketersediaan bahan baku } \\
\text { berbasis potensi lokal, sehingga dinamakan dengan FAKTOR RISET PENGEMBANGAN } \\
\text { TERHADAP KETERSEDIAAN BAHAN BAKU }\end{array}$ \\
\hline $\begin{array}{l}\text { Komponen } \\
\quad 9\end{array}$ & $\begin{array}{l}\text { Komponen ini berisi } 2 \text { variabel yang mempresentasikan preferensi pelaku industri terhadap } \\
\text { tenaga kerja dan upah, sehingga dinamakan FAKTOR TINGKAT PENDIDIKAN DAN } \\
\text { STANDAR HIDUP TENAGA KERJA }\end{array}$ \\
\hline $\begin{array}{l}\text { Komponen } \\
10\end{array}$ & $\begin{array}{l}\text { Komponen ini berisi } 2 \text { variabel yang merepresentasikan preferensi pelaku usaha memilih } \\
\text { lokasi terkait regulasi pemerintah, maka faktor ini dinamakan FAKTOR REGULASI } \\
\text { PEMERINTAH }\end{array}$ \\
\hline
\end{tabular}

Sumber: Hasil analisis SPSS, 2017

Kebijakan 2 tentang diperbolehkannya lokasi dekat dengan bahan baku/ berbahan baku lokal merupakan variabel yang memberikan pengaruh sangat positif bagi pengusaha untuk memilih lokasi industrinya dengan nilai rata-rata 3,582. Pengaruh sangat positif ini dapat berarti bahwa ketentuan dimaksud mempermudah pelaku industri untuk memilih lokasi aktivitas produksi. Pada dasarnya variabel kebijakan 2 dapat digunakan sebagai alat legalisasi investasi industri, namun arahan umum ini tidak memiliki penjelasan lebih lanjut. Penjelasan terhadap ketentuan "lokal" perlu diselaraskan dan tidak hanya membatasi bahan baku lokal yang berasal dari lokal setempat atau kabupaten saja dan tidak juga hanya terbatas sebagai bahan baku mentah..

Sementara, kebijakan 3 yang mengatur industri besar dan menengah harus berada di kawasan peruntukan tertentu merupakan variabel yang memberikan pengaruh negatif dengan nilai rata-rata 1,764 . Pengaruh negatif ini dapat dikatakan bahwa variabel/ ketentuan dimaksud menghambat pelaku industri untuk memilih lokasi aktivitas produksi yang 
diinginkan. Peneliti menganggap pengaruh negatif kebijakan 3 ini disebabkan oleh lokasi yang ditawarkan tidak sesuai dengan karakteristik aktivitas industri saat ini atau tidak memenuhi kriteria yang dibutuhkan..

\section{HASIL DAN PEMBAHASAN}

Kategori I dan II merupakan kelompok industri besar dan menengah dengan ketergantungan terhadap industri suplayer sejenis. Keterkaitan terhadap industri hulu menyebabkan industri pada skala ini cenderung beraglomerasi mendekat pada lokasi pengelompokan industri eksisting. Kecenderungan mengelompok (clustered) ini diketahui dari hasil analisis nearest neighbour dengan nilai p-value 0,044516 dan z-score -2,009199, menunjukkan nilai pada rentang yang signifikan menolak hipotesis nol $\left(\mathrm{H}_{0}\right)$ dengan persebaran yang mengelompok. Fenomena aglomerasi industri besar dan menengah ini selaras dengan yang disampaikan oleh Weber (1909) dan McCann \& Folta (2008) bahwa industri memiliki kecenderungan beraglomerasi untuk mendapatkan keuntungan dan memiliki ketergantungan lokasional antar industri (Hotelling, 1929) sebagai representasi pengaruh jarak. Selain aglomerasi, representasi jarak yang lain terlihat dari lokasi yang cenderung dekat dengan pusat perkotaan, dalam rangka terhubung dengan jaringan bisnis industri, sebagaimana dinyatakan dari hasil penelitian Polèse et al. (2007).

Selain faktor jarak masih berpengaruh, pada satu sisi yang lain pengaruh perkembangan teknologi dan perdagangan global juga terlihat pada pemilihan lokasi industri ini. Hal tersebut terlihat dari cakupan pasar global/ ekspor yang menjadi tujuan pemasaran produk dan industri yang menggunakan input dari sumber impor. Faktor jarak menjadi tidak berpengaruh besar terhadap lokasi produksi (Gorter \& Nijkamp, 2015) karena kemudahan teknologi informasi dan transportasi. Pemilihan lokasi juga terlihat dipengaruhi kuat oleh pengambil keputusan kunci dalam organisasi perusahaan, selaras dengan pendapat dari Gatfield \& Yang (2006) dan Szymanska \& Plaziak (2014). Organisasi perusahaan dalam hal ini menganggap penting nilai historis lokasi industri yang sudah berjalan lama sampai dengan saat ini walaupun kondisi industri suplayer input produksi dari sumber lokal berkurang.

Ketergantungan terhadap konten lokal yang tinggi berupa bahan baku mentah pada industri kategori III, yaitu pengolahan gula kelapa, menyebabkan industri ini cenderung mendekat dan beraglomerasi di sekitar lokasi bahan baku. Sifat perishable bahan baku menuntut proses pengolahan yang cepat dari waktu pengambilannya. Aglomerasi industri karena berorientasi pada bahan baku seperti penelitian yang dilakukan Bargos et al. (2016) Bargos et al. (2016) dan selaras dengan teori lokasi produksi pertanian yang disampaikan oleh von Thunen (Jovanovic, 2003 dan Rustiadi et al., 2009), pada konsep kedekatan lahan pertanian dengan komoditas yang mudah rusak dengan lokasi pengolahan/ pemasaran. Aglomerasi industri kategori IV sebagaimana terjadi juga pada industri dengan karakteristik lokal kategori V, disebabkan/ menunjukkan gejala lokasi spontan sebagaimana dijelaskan oleh Djojodipuro (1992). Gejala tersebut terutama karena pengaruh dari potensi lokal tenaga kerja. Replikasi industri terjadi dari pelaku usaha yang pada mulanya merupakan tenaga kerja industri yang lain sejenis dan berlokasi di sekitar industri pendahulunya. Replikasi ini tidak bersifat mudah dilakukan di lokasi lain yang tidak memiliki embrio, karena lingkungan usaha dan karakteristik tenaga kerja yang spesifik diantaranya telah memiliki brand image lokasi. Industri kategori VI memiliki keterkaitan dan ketergantungan terhadap industri besar dan menengah sebagai pasar hasil produksinya. Aglomerasi industri menunjukkan gejala lokasi spontan seperti yang terjadi pada kategori IV dan V dan dipengaruhi oleh faktor tenaga kerja serta keterkaitan antar industri sejenis terhadap skala industri besar dan menengah.

Kesepuluh faktor yang berpengaruh terhadap pemilihan lokasi IBPL di Kabupaten Banyumas cenderung menunjukkan ciri industri tradisional/ traditional industries 
sebagaimana disampaikan oleh Gatfield \& Yang (2006) atau dipengaruhi oleh faktor lokasi tradisional yang biasa disebut hard factors (An et al., 2014). Ciri yang mengarah kepada new emerging industries hanya sedikit ditunjukkan oleh beberapa industri, dalam hal ini elemen ketergantungan bahan baku/ kedekatan jarak terhadap bahan baku yang cenderung rendah karena pengaruh kemajuan teknologi transportasi. Selain ketergantungan bahan baku yang cenderung rendah, pada beberapa industri menunjukkan ciri ketergantungan terhadap jaringan bisnis/ network relationship. Ketergantungan tersebut ditunjukkan pada tujuan pemasaran global maupun tujuan pemasaran domestik di kawasan perkotaan. Elemen ini dari hasil analisis faktor merupakan faktor lokasi yang berpengaruh kedua terhadap pemilihan lokasi industri.

Terkait dengan variabel kebijakan, variabel ini merupakan faktor eksternal dari organisasi besar pemerintahan di luar perusahaan yang memberikan pengaruh terhadap pemilihan lokasi industri, sebagaimana disampaikan oleh Chapman \& F Walker (1991). Kinerja atau pengaruh kebijakan terhadap pelaku usaha dalam memilih lokasi aktivitas produksi dilihat dari sejauhmana kebijakan telah mengadopsi dengan baik preferensi pelaku industri. Pengaruh negatif ini dapat dikatakan bahwa variabel/ ketentuan dimaksud menghambat pelaku industri untuk memilih lokasi aktivitas produksi yang diinginkan. Pengaruh negatif kebijakan terjadi karena ketentuan yang bersifat arahan umum tidak memiliki penjelasan lebih lanjut. Oleh karenanya kebijakan tersebut perlu dijabarkan dalam bentuk ketentuan pengendalian pemanfaatan ruang, antara lain yang terkait dengan ketentuan industri pada alokasi ruang lainnya

\section{KESIMPULAN}

Karakteristik pengelompokan industri erat kaitannya dengan karakteristik potensi lokal/ konten lokal yang digunakan oleh industri yang dibedakan menjadi enam kategori industri. Setidaknya terdapat empat tipe lokasi yang menjadi preferensi IBPL menurut skalanya dan karakteristik konten lokal yang digunakan dalam produksi. Karakteristik aglomerasi IBPL dipengaruhi oleh dua faktor lokasi yang dominan. Pertama adalah variabel aksesibillitas terhadap potensi lokal yang diartikan sebagai modal dasar utama yang dilihat oleh pelaku sebagai individu yang berperilaku dominan dalam pengambilan keputusan lokasi. Kedua, adalah faktor aksesibilitas terhadap jaringan bisnis terkait dengan perkembangan teknologi informasi dan transportasi. Perkembangan tersebut meningkatkan efisiensi untuk mendapatkan input produksi dan hubungan pemasaran pada pusat-pusat bisnis perkotaan di mana jaringan bisnis pemasaran dikembangkan, diantaranya terhadap CBD di perkotaan utama Kabupaten Banyumas.

Kebijakan alokasi ruang industri yang ditetapkan secara umum dalam RTRW, dianggap belum optimum dan mengena secara keseluruhan oleh para pelaku IBPL. Kebijakan yang kurang mendukung terkait kewajiban berlokasi pada kawasan tertentu/ KPI untuk skala industri besar dan menengah. Pelaku industri lebih optimis bila diberikan keleluasaan memilih lokasi baik di perkotaan maupun mendekati bahan baku lokal, walaupun bahan baku lokal dimaksud bukan dalam pengertian "lokal setempat" dan "bahan baku mentah". Evaluasi terhadap substansi ketentuan ruang aktivitas IBPL dalam RTRW Kabupaten Banyumas diarahkan untuk mengakomodir karakteristik persebaran industri eksisting sebagai ruang yang diperuntukkan bagi industri. Ketentuaan alokasi ruang peruntukan industri yang bersifat arahan umum dioperasionalisasikan lebih mendetil melalui ketentuan umum zonasi industri berpedoman pada karakteristik industri dan faktor lokasi yang berpengaruh dari hasil penelitian ini. Substansinya berupa aturan aktivitas industri pada alokasi pola ruang kegiatan lainnya dan memuat batasan ruang serta jenis kegiatan industri yang bisa dilaksanakan melalui konsep pola ruang mixed use plan. Operasionalisasi kebijakan tersebut termasuk memuat di dalamnya kebijakan insentif dan disinsentif dan 
perluasan pada definisi bahan baku lokal yang didasarkan dari kategori lokal pada inputoutput produksi industri saat ini.

\section{UCAPAN TERIMA KASIH}

Terima kasik kepada Taufik Rudi Ariyanto, karyawan Dinas Perindustrian dan Perdagangan Kabupaten Banyumas untuk dukungan penyediaan data sekunder industri, khususnya data Industri Kecil Menengah (IKM) Kabupaten Banyumas.

\section{DAFTAR PUSTAKA}

An, Y., Kang, Y., \& Lee, S. (2014). A study on the impact of soft location factors in the relocation of service and manufacturing firms. International Journal of Urban Sciences, (May 2014), 1-13. http://doi.org/10.1080/12265934.2014.893834

Assink, M., \& Groenendijk, N. (2009). Spatial Quality, Location Theory and Spatial Planning. In Regional Studies Association Annual Conference 2009 Understanding and Shaping Regions: Spatial, Social and Economic Futures (pp. 1-12). Retrieved from http://purl.utwente.nl/publications/71952

Badri, M. A. (2007). Dimensions of Industrial Location Factors: Review and Exploration. Business and Public Affairs, 1(2), 1-26. Retrieved from http://www.scientificjournals.org/journals2007/articles/1178.pdf.

Bargos, F. F. F., Lamas, W. de Q., Bargos, D. C. C., Neto, M. B. B., \& Pardal, P. C. P. M. (2016). Location problem method applied to sugar and ethanol mills location optimization. Renewable and Sustainable Energy Reviews, 65, 274-282. http://doi.org/10.1016/j.rser.2016.06.079

Capello, R. (2014). Classical Contributions: Von Thunen, Weber, Christaller, Losch. In M. M. Fischer \& P. Nijkamp (Eds.), Handbook of Regional Science (pp. 507-526). Berlin, Heidelberg: Springer Berlin Heidelberg. http://doi.org/DOI 10.1007/978-3-642-23430-9

Chan, Y. (2011). Location Theory and Decision Analysis (2nd editio). Springer Berlin Heidelberg. http://doi.org/10.1007/978-3-642-15663-2

Chapman, K., \& F Walker, D. (1991). Industrial Location: Principles and Policies (2nd Editio). Oxford, UK: Blackwell, 108 Cowley Road, Oxford, OX4 1JF, UK.

Djojodipuro, M. (1992). Teori Lokasi. Jakarta: Lembaga Penerbit Fakultas Ekonomi Universitas Indonesia (FEUI).

Elliott, F. E. (1948). Locational Factors Affecting Industrial Plants. In Economic Geography (Vol. 24, pp. 283285). Clark University. Retrieved from http://www.jstor.org/stable/141309

Fahmi, F. Z., Koster, S., \& van Dijk, J. (2016). The Location of Creative Industries in A Developing Country: The Case of Indonesia. Cities, 59, 66-79. http://doi.org/10.1016/j.cities.2016.06.005

Fischer, M. M., \& Nijkamp, F. (2014). Handbook of Regional Science. (M. M. Fischer \& F. Nijkamp, Eds.) Handbook of Regional Science. Springer Heidelberg New York Dordrecht London. http://doi.org/10.1007/978-3-642-23430-9

Fujita, M. (2010). The Evolution of Spatial Economics: From Thunen to The New Economic Geography. Japanese Economic Review, 61(1), 1-32. http://doi.org/10.1111/j.1468-5876.2009.00504.x

Gatfield, T., \& Yang, C. (2006). New Industrial Space Theory - A Case Study and Empirical Analysis of Factors Effecting Newly Emerging Key Industries In Queensland. Australasian Journal of Regional Studies, 12(1), 47-61. Retrieved from http://anzrsai.org/assets/Uploads/PublicationChapter/81-4GatfieldYang.pdf

Gorter, C., \& Nijkamp, P. (2015). Location Theory. International Encyclopedia of the Social \& Behavioral Sciences (Second Edition), 14, 287-292. http://doi.org/10.1016/B978-0-08-097086-8.72029-0

Hall, P. (2000). Creative Cities and Economic Development. Urban Studies, 37(4), 639-649. http://doi.org/10.1080/00420980050003946

Harrington, J. W., \& Warf, B. (1995). Industrial Location: Principles, Practice, and Policy. New York, NY: Routledge 2 Park Square, Milton Park, Abingdon, Oxfordshire OX14.

Hatcher, L., \& O’Rourke, N. (2013). A Step-by-Step Approach to Using SAS for Factor Analysis and Structural Equation Modeling. Retrieved from http://www.google.com.tr/books?id=dqNku94w1dIC

Jovanovic, M. N. (2003). Local vs. Global Location of Firms and Industries. Journal of Economic Integration, 18(1), 60-104. http://doi.org/10.2307/23000732

Kimelberg, S. M., \& Nicoll, L. A. (2012). Business Location Decisions in the Medical Device Industry: Evidence from Massachusetts. Economic Development Quarterly, 26(1), 34-49. http://doi.org/10.1177/0891242411430327 
McCann, B. T., \& Folta, T. B. (2008). Location Matters: Where We Have Been and Where We Might Go in Agglomeration Research. Journal of Management, 34(3), 532-565. http://doi.org/10.1177/0149206308316057

Needham, B., Louw, E., \& Metzemakers, P. (2013). An economic theory for industrial land policy. Land Use Policy, 33, 227-234. http://doi.org/10.1016/j.landusepol.2013.01.005

Pen, C. (1999). Improving the behavioural location theory: Preliminary results of a writen questionnaire about strategic decision-making on firm relocation. European RSA Congress Regional Cohesion and Competitiveness in 21st Century Europe, Dublin. Retrieved from http://wwwsre.wu.ac.at/ersa/ersaconfs/ersa99/Papers/a166.pdf

Polèse, M., Rubiera-Morollon, F., \& Shearmur, R. (2007). Observing regularities in location patterns: An analysis of the spatial distribution of economic activity in Spain. European Urban and Regional Studies, 14(2), 157-180. http://doi.org/10.1177/0969776407077188

Rustiadi, E., S, S., \& Panuju. (2009). Perencanaan dan Pengembangan Wilayah. Jakarta: Yayasan Pustaka Obor Indonesia.

Smith, D. M. (1966). A Theoretical Framework for Geographical Studies of Industrial Location. Economic Geography, 42(2), 95-113. $\quad$ Retrieved from https://www.researchgate.net/publication/305208450_A_Theoretical_Framework_for_Geographical_ Studies_of_Industrial_Location

Songmei, L. (2005). High tech spatial concentration human capital, agglomeration economies, location theories and creative cities. The University of Louisville's Institutional Repository. http://doi.org/http://dx.doi.org/10.18297/etd/824

Sugiyono, P. D. (2016). Metode Penelitian Kuantitatif, Kualitatif, dan R\&D. Bandung: CV. Alfabeta.

Szymanska, A., \& Plaziak, M. (2014). Enterprise and classical factors of its location on the market. Procedia Social and Behavioral Sciences, 120, 13-22. http://doi.org/10.1016/j.sbspro.2014.02.076 . (2016). Kabupaten Banyumas Dalam Angka 2016. BPS Kabupaten Banyumas.

2011. Peraturan Daerah Kabupaten Banyumas Nomor 10 Tahun 2011 tentang Rencana Tata Ruang Wilayah (RTRW) Kabupaten Banyumas Tahun 2011-2031. 